\title{
To Spend or Not To Spend? An Empirical Analysis of the Fundamental Role of State Governments in Economic Output
}

\author{
By Stephen Holt, Matt McCreary, and Lindsay Haslebacher
}

Amidst an economic recession and a long period of high rates of unemployment, the appropriate role of government expenditures in creating economic growth has become a major feature in current political discourse at both the federal and state level. This article uses an endogenous growth model to examine the fundamental relationship of state-level government spending and per capita GDP. Specifically, the analysis uses state-level data covering a six-year period controlling for state workforce characteristics, distribution of industrial activities, and tax revenue sources to develop a working model of state economies. The analysis found that state government spending had a positive, statistically significant effect on per capita GDP. The marginal return in per capita GDP for an additional dollar per capita of public expenditure was found to be between $\$ 1.89$ and $\$ 2.39$. In addition, indicator variables for political party in power were added to examine correlations between political party control and economic outcomes. The political party in power had no significant effect on GDP. The positive, statistically significant correlation between GDP and public expenditures alongside political variables with no significant effect on GDP indicates specific policies implemented by state governments may have more explanatory power of economic output than political party control.

\section{Introduction}

Over the seven months following the collapse of the housing market in late 2008, which sparked a chain collapse of highly leveraged banks, the United States' nominal Gross Domestic Product (GDP) declined by 4 percent, financial institutions posted losses in the trillions, the United States' stock market dropped by 40 percent, and the United States economy lost 4.1 million jobs (Johnson and Kwak 2010; CBO 2009a). National unemployment grew exponentially over the years, hitting 10.1 percent in October of 2009 (Lynch 2010) and remaining above 8.5 percent until December of 2011 (Bureau of Labor Statistics 2011); still significantly higher than the 5.2 percent unemployment rate necessary for "full employment" (Weisbrot 2010). In late 2008, in response to the pending collapse of financial markets, the Democratically controlled Congress and Republican President George W. Bush passed the Troubled Assets Relief Program, injecting $\$ 700$ billion dollars into the financial sector to alleviate the pressures in the system caused by securities rapidly declining in value (Palmer 2011; Johnson and Kwak 2010). Shortly after the passage and implementation of Troubled Assets Relief Program, in 2009, aiming to address the economic fallout caused by the collapse, newly elected President Barrack Obama passed the American Recovery and Reinvestment Act. This legislation aimed at stimulating economic demand by inject- 
ing public investment and consumption dollars into the economy ( $\mathrm{CBO}$ 2011a). Of the $\$ 819$ billion total package, the bill included $\$ 637$ billion in direct spending provisions and $\$ 182$ billion in targeted tax cuts (Yourish and Stanton 2009).

The economic downturn in 2008 drove a 6.6 percent decline in tax receipts in fiscal year 2009 (CBO 2009a). Coupled with the increased stimulus spending, short-run deficits soared. The economic downturn and the subsequent substantial increase in unemployment, particularly long-term unemployment, triggered national debates about the most effective and appropriate way to resolve the economic crisis. Consequently, the role of government, government spending, and government deficits became a prevalent theme in the national debate. Many economists believed that the size and depth of the downturn required stimulus spending, in addition to the funds provided by the American Recovery and Reinvestment Act, to address sluggish economic growth (Media Matters 2010). Economist Christina Romer, advised the design of the Obama administration's policy response to the economic crisis, suggested that between $\$ 1.2$ trillion and $\$ 2$ trillion of government stimulus would be necessary to overcome such a large economic downturn (Lizza 2009). Gary Burtless, an economist at the Brookings Institution, writes, "in the near term, the government should boost spending or keep taxes down in order to spur faster economic growth." (Burtless 2010) The International Monetary Fund called on national governments around the world to increase stimulus spending to improve the efficacy of stimulus measures internationally. Despite some growth from stimulus measures in the United States, the International Monetary Fund estimates show more would be needed to replace the significant losses from the recession (Freedman et al. 2009). In addition to the various calls for additional spending, the Congressional Budget Office estimates that in the base year alone (FY 2009), the American Recovery and Reinvestment Act, with direct spending equal to about half of the estimated need, led to the creation of an additional 600,000 to 1.6 million jobs, with an estimated GDP increase of 1.2 percent to 3.2 percent (CBO 2009b). The initial estimates appear to indicate positive effects from stimulus measures; however, the modest increase in GDP estimated by the Congressional Budget Office seems to confirm observations that the American Recovery and Reinvestment Act stimulus response was insufficient in addressing the size and depth of the 2008 recession.

Despite the call from some economists and organizations for more stimulus measures, the political environment constrains passage of additional spending measures. Disagreement between the two parties on the role of government and the efficacy of government spending impede basic governmental operations potentially further endangering the economy. For instance, over the summer of 2011, Republicans refused to raise the debt ceiling, a typically uncontroversial necessity to continue funding the government, in order to demand significant reductions in government spending. The months of negotiation required to reach an agreement highlighted the depth of this divide and potential dangers of continuation. The government nearly defaulted on its debt; a circumstance that many believe would have had dire consequences for the economy (Calmes and Hulse 2011). Consequently, in a period of rampant unemployment, while many economists called for additional stimulus spending, the administration negotiated a deficit reduction package, the Budget Control Act of 2011, which committed to reducing spending by $\$ 2.1$ trillion over the next decade (CBO 2011b). The issue of government spending promises to remain prevalent into the coming years as well. For instance, Representative Paul Ryan (R-WI) has introduced bills in two consecutive years calling for $\$ 6.2$ trillion dollars in spending reductions (House 
Committee on the Budget 2012). In addition, Republican voters identify government spending and government power as their number one issue (Newport 2011).

State and local government debates about state government spending and state spending reduction policies reflect the national debates about federal government spending. Reports from the Bureau of Economic Analysis indicate that state and local government expenditures have declined steadily since 2008. Such reductions correlate with negative quarterly contributions to GDP that partially offset 2011 GDP growth driven by an increase in personal consumption expenditures (United States Bureau of Economic Analysis 2012). The efforts to reduce state government spending emanate from both Democrats and Republicans. In New York, Democratic Governor Andrew Cuomo proposed a fiscal year 2012 budget with $\$ 8.5$ billion less spending than the prior year (New York State Government 2012). Meanwhile, in Florida, Republican Governor Rick Scott proposed a fiscal 2012 budget with a $\$ 3.17$ billion reduction in government spending (Office of Governor Rick Scott 2012). Despite negative economic effects that correlate with reductions in state government spending, the political response appears to be reductions in state spending from both parties. Given the findings of the Bureau of Economic Analysis report, a disconnection seems to exist between the political environment, the policies being implemented, and the goal of economic growth.

Within the framework established in this paper, identifying the fundamental effects and effectiveness of government spending on economic output is the primary focus. Using data gathered by the faculty of The New York University from Bureau of Labor Statistics statistical abstracts, an endogenous growth model was constructed to isolate the fundamental economic effects of state government expenditures. In addition, the politicization of the economic effects of all forms of government spending appears to create a disconnection between policy needs and policy implementation. Since party campaign rhetoric on economic policy serves to politicize the issue, after developing an economic model for examining endogenous growth across states, the final model discusses political variables to estimate correlations between the party in power and economic outcomes. Including political variables in the final model allows comparisons of the relative importance of government policy, as represented by expenditures, and political party control for economic growth. As the analysis will show, the rhetorical misrepresentation of this issue across both parties, as introduced here, leads to far wider variance in economic outcomes associated with the political variables compared to the expenditure variables. The comparison indicates economic policies implemented by state governments carry greater effects in economic growth than party affiliation of state government legislatures and executives.

\section{Model Specification Precedents}

In order to isolate the effects of government expenditure and political parties on state economic outcomes, complex, multivariate state economies and activities were modeled. The analysis in this paper adopts a modified endogenous growth model in order to estimate the effects of state economic inputs and control for variance in those inputs across states. Over the last three decades, much work has been done in developing new strategies for using endogenous growth models to analyze the relationship of government spending to economic output. Robert J. Barro, an economist and professor at Harvard University, prompted a rethinking of this relationship in developing a theoretical model for endogenous economic growth. Endogenous economic growth models examine the relative contributions to economic output of factors within an economy. Barro developed a model that compared 
the effects of government consumption spending (the purchase of goods and services by governments) versus government investment spending (the building of public goods for productive purposes [e.g. roads, human capital]) (Barro 1988). Later, Barro tested his theoretical model using cross-sectional data from 98 countries (Barro 1991). While his work found statistically significant, negative impacts of government consumption spending, he found statistically insignificant, but positive economic output effects of government investment spending (Barro 1991).

Later research modeling endogenous growth used cross-sectional and time series economic data on 113 countries in diverse economic, political, and operational contexts into a single model and tested the validity of such an approach (Grier and Tullock 1989). The study examined per capita GDP to control for variance in initial levels of wealth, and controlled for population growth to proxy for labor participation growth. Since endogenous economic growth can be affected by the level of human capital available in an economy, a model comparing multiple economies must control for the variance in human capital resources across economies (Grier and Tullock 1989); however, the study examined the effect of government size on output. The model used the proportion of total GDP represented by government spending and found a negative relationship (Grier and Tullock 1989).

More recent studies have also used endogenous growth models to examine the relationship between government expenditures and economic output. One study examined the impacts of government spending on per capita GDP in Turkey using data from 1987 to 2006. Again, governmental consumption spending on goods and services had no significant impact on GDP, but public investment spending had a significant positive effect (Taban 2010). A similar study used timeseries data on Malaysian economic activity between 1970 and 2006 to examine the effects of government spending on GDP. The study began with a bivariate model to provide a baseline estimate, and integrated groups of variables to test sensitivity. The bivariate model found a negative effect of government spending on economic growth; however, the multivariate models indicated a positive relationship between government spending and economic growth (Govindaraju, et al. 2010).

The literature surrounding endogenous growth models and the relationship of government spending and economic output indicates mixed results. While public consumption expenditures were found to have a wide variance in effects, public investment expenditures consistently reflected a positive, statistically significant relationship with economic growth. Such findings indicate that government expenditures can provide a multiplier effect on inputs for private production through public investment spending in order to create economic growth. Government activities focused on human capital development (such as providing access to education) and infrastructure improvements (such as building roads, utilities, and railways) can supplement, rather than supplant, private sector economic activity and increase output in the economy overall.

\section{Data and Methods}

Drawing on the literature of endogenous growth models, the analysis in this study used panel data to from the 50 US states (not including DC) to construct an endogenous growth model and explore the relationship of state government spending and economic output. The data include four observation points spanning six years (United States Census Bureau 2011). The data allowed for a sample of 200 observations; a sample size large enough to reach conventional levels of statistical significance. Since the literature found consistent, strong evidence of a positive relationship between public investment expenditures and growth, using the states as a 
unit of analysis is appropriate. Particularly in the United States, state governments make many of the allocation decisions on education and transportation funding. Further, as component units of the same national government and subject to the same exogenous economic conditions, using state governments to estimate growth provide better estimates than international comparisons that can be subject to differentiated exogenous factors such as access to international trade participation. The analysis draws on prior research in building the economic model, using per capita GDP as an estimate of economic output, beginning with a bivariate model, and adding related variables to test for specification sensitivity. Measuring GDP in per capita allows two major benefits: a control for initial regional variance in human capital quantities and a more intuitive interpretation of expenditure effects. As the economic model used in this study seeks to examine the effects on economic output of state government spending, in economies producing billions of dollars of output, it would not be possible to detect the effect in absolute GDP of one additional dollar of government expenditure.

In a point of departure from previous studies, the model used for this analysis set per capita government expenditures as the dependent variable. Previous studies used the percentage of total GDP represented by government expenditures when estimating endogenous growth in order to control for heteroskedasticity. In a recession, however, government spending as a percent of GDP will likely go up as stimulus measures are taken and public services are more heavily relied upon for support. Consequently, using government spending as a percent of GDP may hide the effects of downturns and generate biased estimates. As the main focus of the analysis is to isolate the efficacy of government expenditure as a source for economic growth, all else held constant, per capita government expenditure was a more appropriate measure.
Although previous studies focused on international comparisons, the federal structure of the United States' government allowed for implementation of a similar endogenous growth model to examine economic outcomes associated with state government spending. The variety of institutions, policy regimes, and political cultures across state governments allowed the model to isolate the fundamental effects of state government spending on economic output. Unfortunately, the data available and included in the study did not allow for direct comparisons among government activities. Such comparisons could provide valuable insights for government administrative and investment decisions, and future study of the subject would be needed for further recommendation. In order to control for variance of internal state characteristics that remain relatively stable over time, such as culture, history, political tendencies, and policy regimes, the study uses a fixed effects regression model, as outlined in Figure 1. Fixed effects models estimate a unique trajectory of the dependent variable, given a set of specified independent variables, for each unit of observation in a panel dataset. The technique allows the model to estimate unique dependent variable value trajectories from each unit of observation's initial value. A fixed effects regression then estimates the minimum variance equation from the panel's unique trajectories. Since the trajectories underlying the final estimates vary according to the values of the individual units of observation, the method controls for variance in unobserved, constant characteristics unique to each unit.

For this study, the unit of observation is states. Using a fixed effects model allows control for variance in unobserved characteristics by estimating the model for each state individually. From these estimates, the model derives a minimum variance estimate across states to model the fundamental effects of government spending on economic output (Studenmund 2005). For instance, states which 
are culturally reluctant to expend public resources on education may see lower economic returns on government spending. By estimating the relationship for each state's economic trajectory uniquely to derive the estimated model across states, a fixed effects model will control for variance caused by an unobserved, constant characteristic, such as local cultural aversion to government spending on education. Controlling for unobservable individual state economic structures, histories, and cultures, in addition to observable and measured state characteristics, allows the model to isolate the fundamental effects of state government expenditure and

Figure 1: Model Specification.

$$
\begin{aligned}
P C G D P=\widehat{\beta_{0}}+ & \widehat{\beta}_{l} P C E_{i}+\widehat{\beta}_{l} B O R_{i}+\widehat{\beta}_{l} M H I_{i}+\widehat{\beta}_{l} U E_{i}+\widehat{\beta}_{l} P B P_{i}+\widehat{\beta}_{l} M P_{i}+\widehat{\beta}_{l} F P_{i}+\widehat{\beta}_{l} U N_{i}+\widehat{\beta}_{l} H S_{i}+\widehat{\beta}_{l} B A_{i} \\
& +\widehat{\beta}_{l} \% A G_{i}+\widehat{\beta}_{1} \% M A N_{i}+\widehat{\beta}_{i} \% F I_{i}+\widehat{\beta}_{l} P C T T X_{i}+\widehat{\beta}_{l} \% P T X_{i}+\widehat{\beta}_{l} \% C T X_{i}+\widehat{\beta}_{l} \% I T X_{i}+\widehat{\beta}_{l} \% S T X_{i} \\
& +\widehat{\beta}_{l} G L A G_{i}+\widehat{\beta}_{l} S L A G_{i}+\widehat{\beta}_{l} H L A G_{i}+\widehat{\beta}_{l} G L A G 2_{i}+\widehat{\beta}_{l} S L A G 2_{i}+\widehat{\beta}_{l} H L A G 2_{i}+Z_{i} \gamma+\mu_{i}+\varepsilon_{i}
\end{aligned}
$$

Where: $\quad$ PCGDP $=$ state gross domestic product (GDP) per capita

$\mathrm{PCE}_{\mathrm{i}}=$ total state expenditures per capita

$\mathrm{BOR}_{\mathrm{i}}=$ total state government borrowing

$\mathrm{MHI}_{\mathrm{i}}=$ mean household income

$\mathrm{UE}_{\mathrm{i}}=$ unemployment rate

$\mathrm{PBP}_{\mathrm{i}}=$ percent of total population below poverty level

$\mathrm{MP}_{\mathrm{i}}=$ percent of total population participation in labor force by males

$\mathrm{FP}_{\mathrm{i}}=$ percent of total population participation in labor force by females

$\mathrm{UN}_{\mathrm{i}}=$ percent of total population union members

$\mathrm{HS}_{\mathrm{i}}=$ percent of population with a high school diploma

$\mathrm{BA}_{\mathrm{i}}=$ percent of population with at least a bachelor's degree

$\% \mathrm{AG}_{\mathrm{i}}=$ percent total GDP from agriculture

$\% \mathrm{MAN}_{\mathrm{i}}=$ percent total GDP from manufacturing

$\% \mathrm{FI}_{\mathrm{i}}=$ percent total GDP from finance

PCTTX $_{\mathrm{i}}=$ total state tax revenue per capita

$\% \mathrm{PTX}_{\mathrm{i}}=$ state property tax revenue (as percentage of total tax revenue)

$\% \mathrm{CTX}_{\mathrm{i}}=$ state corporate net income tax revenue (as percentage of total tax revenue)

\%ITX $=$ state income tax revenue (as percentage of total tax revenue)

$\% \mathrm{STX}_{\mathrm{i}}=$ state sales tax revenue (as percentage of total tax revenue)

$\mathrm{GLAG}_{\mathrm{i}}=$ governor was a Democrat one year prior

$\mathrm{SLAG}_{\mathrm{i}}=$ majority of Senate was Democrat one year prior

$\mathrm{HLAG}_{\mathrm{i}}=$ majority of House was Democrat one year prior

$\mathrm{GLAG}_{2}=$ governor was Democrat two years prior

$\mathrm{SLAG2}_{\mathrm{i}}=$ majority of Senate was Democrat two years prior

$\mathrm{HLAG}_{\mathrm{i}}=$ majority of House was Democrat two years prior

$\mathrm{Z}_{\mathrm{i}} \mathrm{Y}=$ time-invariant regressor to account for fixed effects

$\mu_{\mathrm{i}}=$ state regressor to account for fixed effects 
other economic inputs on GDP output.

\section{Limitations}

There are several limitations in the model, and others related to limitations in the data. First, a possibility of heteroskedasticity exists in the primary economic input of interest, state expenditures. The calculation for GDP is Consumption + Investment + Government Expenditure + (Exports - Imports) (Landefield, et al. 2008). Since government spending is included in the calculation of GDP, there is a high probability for heteroskedasticity when examining the direct effects of state expenditures on GDP. By examining the GDP effects correlated with the proportion of economic activity represented by government expenditure, previous models sought to control for variance in initial government size relative to total economic output in order to minimize heteroskedasticity. While heteroskedasticity does not bias the estimates, it can create lower or higher estimates of variance or error. However, as mentioned above, examining the proportion of GDP represented by government expenditures can bias the estimates; therefore, this model seeks to isolate an unbiased estimate of the marginal returns in economic output associated with public expenditures.

Second, the education variables contain a possibility of multicollinearity. Since the percentage of the population with a bachelor's degree is a direct function of the percentage of the population with a high school diploma, the education variables are likely to be highly correlated with one another. In addition, state provisions through the public education system create a collinear relationship between workforce education levels and state expenditures. As the results show, the estimates for education variables vary widely based on model specification. This contradicts prior research findings concerning education level contributions to economic output, indicating some bias introduced by multicollinearity.
Beyond limitations within the model, there are also limitations in the data, for instance, education data was incomplete. Education levels beyond a bachelor's degree and between a high school diploma and bachelor's degree were omitted from the model due to a lack of data. In addition, specific tax rates were not available, instead leaving the proportion of tax revenues on various activities to proxy for the specific rates. While the proxies provide some insights about the economic output effects associated with different forms of taxation, much more accurate estimates could be obtained from the tax rates. Finally, the data only cover four points across six years. Many policies and economic shifts require a much longer timeframe for effects to be detected. While useful for a preliminary analysis, data across a longer timespan would be needed for more conclusive results.

\section{Results}

In order to account for the sensitivity and accuracy of the model and relevance of the variables included, the independent variables were introduced by group. Table 1 illustrates the results of the regression models. Model 1 captures the relationship between the main independent variable of interest and per capita GDP. Model 2 further isolates the effects of state government spending on per capita GDP by controlling for the debt levels of each state to proxy for missing data on the proportion of state expenditures in the service of debt. As debt reflects spending in previous periods, payments in service of that debt are not expected to influence GDP directly; therefore, to isolate the effects of state spending on GDP, the model needed to control for state spending not expected to influence GDP.

Model 3 adds the workforce characteristics of the states, controlling for the important differences in labor characteristics and talents that shape the economic activities across states. Model 4 adds tax levels to control for variance in approach- 
Table 1: Regression Results with standard errors in parentheses.

\begin{tabular}{|c|c|c|c|c|c|}
\hline Variable & Model 1 & Model 2 & Model 3 & Model 4 & Model 5 \\
\hline 1998 (Constant) & $\begin{array}{l}20,731.06 \\
(1,623.94)^{* * *}\end{array}$ & $\begin{array}{l}20,728.01 \\
(1,628.20)^{* * *}\end{array}$ & $\begin{array}{l}16,283.75 \\
(8,886.54)^{*}\end{array}$ & $\begin{array}{l}12,042.29 \\
(9,894.07)\end{array}$ & $\begin{array}{l}12,372.62 \\
(10,064.42)\end{array}$ \\
\hline 2000 & $\begin{array}{l}2,551.04 \\
(395 \cdot 30)^{* * * *}\end{array}$ & $\begin{array}{l}2,550.92 \\
(396.30)^{* * *}\end{array}$ & $\begin{array}{l}1,738.07 \\
(288.88)^{* * *}\end{array}$ & $\begin{array}{l}1,623.95 \\
(329.29)^{* * * *}\end{array}$ & $\begin{array}{l}1,654.69 \\
(334.49)^{* * *}\end{array}$ \\
\hline 2002 & $\begin{array}{l}2,965.41 \\
(624.86)^{* * *}\end{array}$ & $\begin{array}{l}2,961.29 \\
(627 \cdot 22)^{* * * *}\end{array}$ & $\begin{array}{l}3,514.94 \\
(780.40)^{* * * *}\end{array}$ & $\begin{array}{l}3,669.33 \\
(817.78)^{* * * *}\end{array}$ & $\begin{array}{l}3,854.67 \\
(837.30)^{* * * *}\end{array}$ \\
\hline 2004 & $\begin{array}{l}5,778.91 \\
(776.95)^{* * * *}\end{array}$ & $\begin{array}{l}5,768.72 \\
(782.80)^{* * * *}\end{array}$ & $\begin{array}{l}6,047 \cdot 28 \\
(735 \cdot 26)^{* * *}\end{array}$ & $\begin{array}{l}5,765.13 \\
(826.50)^{* * * *}\end{array}$ & $\begin{array}{l}5,824.84 \\
(834.80)^{* * * *}\end{array}$ \\
\hline Per Capita Expenditures & $\begin{array}{l}2.39 \\
(.47)^{* * * *}\end{array}$ & $\begin{array}{l}2.38 \\
(.47)^{* * * *}\end{array}$ & $\begin{array}{l}2.08 \\
(.39)^{* * * *}\end{array}$ & $\begin{array}{l}1.89 \\
(.42)^{* * * *}\end{array}$ & $\begin{array}{l}1.91 \\
(.43)^{* * * *}\end{array}$ \\
\hline Total Borrowed & & $\begin{array}{l}.00 \\
(.00)\end{array}$ & $\begin{array}{l}.00 \\
(.00)\end{array}$ & $\begin{array}{l}.00 \\
(.00)\end{array}$ & $\begin{array}{l}.00 \\
(.00)\end{array}$ \\
\hline Median Household Income & & & $\begin{array}{l}.16 \\
(.05)^{* * *}\end{array}$ & $\begin{array}{l}.15 \\
(.05)^{* * * *}\end{array}$ & $\begin{array}{l}.14 \\
(.05)^{* * * *}\end{array}$ \\
\hline Unemployment Rate & & & $\begin{array}{l}-258.24 \\
(135.79)^{*}\end{array}$ & $\begin{array}{l}-115.51 \\
(144.85)\end{array}$ & $\begin{array}{l}-122.55 \\
(144.23)\end{array}$ \\
\hline Percent Below Poverty Level & & & $\begin{array}{l}-156.01 \\
(75.82)^{* *}\end{array}$ & $\begin{array}{l}-138.59 \\
(78.87)^{*}\end{array}$ & $\begin{array}{l}-104.90 \\
(79.57)\end{array}$ \\
\hline Male Labor Force Participation & & & $\begin{array}{l}89.08 \\
(77.13)\end{array}$ & $\begin{array}{l}118.34 \\
(78.51)\end{array}$ & $\begin{array}{l}134.19 \\
(79.39)^{*}\end{array}$ \\
\hline Female Labor Force Participation & & & $\begin{array}{l}-8.84 \\
(86.97)\end{array}$ & $\begin{array}{l}-17.41 \\
(88.77)\end{array}$ & $\begin{array}{l}-21.80 \\
(88.72)\end{array}$ \\
\hline $\begin{array}{l}\text { Percent of Labor Force Union } \\
\text { Members }\end{array}$ & & & $\begin{array}{l}-146.70 \\
(85.57)^{*}\end{array}$ & $\begin{array}{l}-125.65 \\
(86.42)\end{array}$ & $\begin{array}{l}-101.59 \\
(89.74)\end{array}$ \\
\hline $\begin{array}{l}\text { Percent of Population Graduated } \\
\text { from High School }\end{array}$ & & & $\begin{array}{l}-124.65 \\
(59.96)^{* *}\end{array}$ & $\begin{array}{l}-98.98 \\
(62.16)^{* *}\end{array}$ & $\begin{array}{l}-116.53 \\
(66.03)^{*}\end{array}$ \\
\hline $\begin{array}{l}\text { Percent of Population with a Bach- } \\
\text { elor's Degree }\end{array}$ & & & $\begin{array}{l}-15.44 \\
(57.62)\end{array}$ & $\begin{array}{l}-30.52 \\
(59.62)\end{array}$ & $\begin{array}{l}-9.14 \\
(60.41)\end{array}$ \\
\hline $\begin{array}{l}\text { Percent of Total GDP from Agri- } \\
\text { culture }\end{array}$ & & & $\begin{array}{l}331.86 \\
(178.65)^{*}\end{array}$ & $\begin{array}{l}339.21 \\
(181.05)^{*}\end{array}$ & $\begin{array}{l}335.91 \\
(180.61)^{*}\end{array}$ \\
\hline $\begin{array}{l}\text { Percent of Total GDP from Manu- } \\
\text { facturing }\end{array}$ & & & $\begin{array}{l}396.64 \\
(74.21)^{* * *}\end{array}$ & $\begin{array}{l}385.24 \\
(74.98)^{* * * *}\end{array}$ & $\begin{array}{l}374.32 \\
(76.76)^{* * *}\end{array}$ \\
\hline $\begin{array}{l}\text { Percent of Total GDP from Finance, } \\
\text { Insurance, Real Estate }\end{array}$ & & & $\begin{array}{l}130.32 \\
(119.08)\end{array}$ & $\begin{array}{l}142.76 \\
(119.99)\end{array}$ & $\begin{array}{l}146.38 \\
(120.37)\end{array}$ \\
\hline Per Capita Tax Revenues & & & & $\begin{array}{l}1.65 \\
(.87)^{*}\end{array}$ & $\begin{array}{l}1.76 \\
(.88)^{* *}\end{array}$ \\
\hline $\begin{array}{l}\text { Percent of Tax Revenue from } \\
\text { Property Tax }\end{array}$ & & & & $\begin{array}{l}-47.08 \\
(38.38)\end{array}$ & $\begin{array}{l}-62.79 \\
(40.40)\end{array}$ \\
\hline $\begin{array}{l}\text { Percent of Tax Revenue from Corpo- } \\
\text { rate Income Tax }\end{array}$ & & & & $\begin{array}{l}12.96 \\
(83.79)\end{array}$ & $\begin{array}{l}3.06 \\
(85.40)\end{array}$ \\
\hline $\begin{array}{l}\text { Percent of Tax Revenue from Per- } \\
\text { sonal Income Tax }\end{array}$ & & & & $\begin{array}{l}10.56 \\
(57.78)\end{array}$ & $\begin{array}{l}13.89 \\
(58.03)\end{array}$ \\
\hline $\begin{array}{l}\text { Percent of Tax Revenue from Sales } \\
\text { Tax }\end{array}$ & & & & $\begin{array}{l}-43.90 \\
(53.87)\end{array}$ & $\begin{array}{l}-61.49 \\
(54.77)\end{array}$ \\
\hline Governor was a Democrat Last Year & & & & & $\begin{array}{l}-207.59 \\
(213.53)\end{array}$ \\
\hline $\begin{array}{l}\text { Democrat Majority in the Senate } \\
\text { Last Year }\end{array}$ & & & & & $\begin{array}{l}454.74 \\
(353.57)\end{array}$ \\
\hline $\begin{array}{l}\text { Democrat Majority in the House } \\
\text { Last Year }\end{array}$ & & & & & $\begin{array}{l}-253.75 \\
(332.12)\end{array}$ \\
\hline $\begin{array}{l}\text { Governor was a Democrat } 2 \text { Years } \\
\text { Ago }\end{array}$ & & & & & $\begin{array}{l}220.55 \\
(294.45)\end{array}$ \\
\hline $\begin{array}{l}\text { Democrat Majority in the Senate } 2 \\
\text { Years Ago }\end{array}$ & & & & & $\begin{array}{l}-342.29 \\
(313.42)\end{array}$ \\
\hline $\begin{array}{l}\text { Democrat Majority in the House } 2 \\
\text { Years Ago }\end{array}$ & & & & & $\begin{array}{l}-329.23 \\
(315 \cdot 37)\end{array}$ \\
\hline
\end{tabular}

Note: $\left.{ }^{*}=(\mathrm{p}<.10) ;{ }^{* *}=(\mathrm{p}<.05) ;{ }^{* * *}=(\mathrm{p}<.01)\right)$ 
es to policies across states and to outline the particular economic effects of specific tax policies. Model 5 represents the full model, incorporating the political environment of the state, comparing the effects of the party in power on the state economy, as captured by the per capita GDP.

\section{Models 1 and 2: State Spending and the Economy}

The recession and continuing high unemployment has prompted a public focus on the appropriate and most effective role for government in economic affairs. Previous research has shown that the strongest force in reducing unemployment requires economic growth above and beyond government outlays and prior year private consumption (Barro 1977). Such growth implies a state economies' need for innovation in products and businesses and growth in quality and productive capacity of human capital. Can such growth be sparked by state government spending and investments? Further, what is marginal return in economic growth per dollar spent by state governments, regardless of the state operational context or the functional activities supported by those dollars?

In seeking answers to these questions, a basic estimate of the marginal economic returns to state government expenditure was calculated. The marginal return per dollar spent by state governments can provide insights into the fundamental role for government in managing economic growth and reversing economic contraction. As Model 1 indicates, there is a positive, statistically significant correlation between per capita state expenditures and per capita GDP. As the model shows, for one dollar per capita spent by the state government, per capita GDP grew by $\$ 2.39$. The variance in the relationship is relatively small (47 cents), indicating a very strong relationship. Even when controlling for state government borrowing in Model 2, the large returns in per capita GDP resulting from state spending remain. Controlling for borrow- ing only reduces the impact by one cent and does not change the standard error.

Since the calculation for GDP includes government expenditure; the positive relationship is to be expected. However, the effect size of the spending, over 100 percent returns per dollar spent is of particular interest. A marginal return of less than one dollar would indicate deadweight losses and inefficiencies, implying that state governments may be operating at a size of diminishing returns or that state government expenditure may not be the most effective way to spark economic growth. The large returns, however, point to the fundamental importance of state government expenditure in economic activity, and carry implications for the effectiveness of state government expenditure in sparking economic growth, particularly in times of economic contraction. Given the variance across states in government size, role, and expenditures, such high marginal returns of state government expenditure emphasize the fundamental importance of government in economic growth.

\section{Model 3: Workforce Characteristics}

In Model 3, several attributes of the labor force that vary across states were included to further isolate the effect of state government spending on GDP. Some of the variables describing workforce characteristics, such as union membership, education levels, gender composition of the workforce, and income distribution proxies, are included as prior research indicates they influence one or more elements of GDP. Others, such as the proportion of GDP represented by different industries, are included to examine their influence on one or more elements of GDP. Including these variables helps control for variance in GDP outcomes across states driven by differences in economic structure.

The workforce characteristics variables (excluding the industry variables) are included because at a fundamental level they are believed to effect 
income. Income represents a driving force in private consumption and investment options and decisions, which, in the aggregate, affects the consumption, investment, and trade components of GDP. Both the levels and distribution of wages impact GDP in important ways. Prior research on developing nations has shown that income inequality increases political instability and deters investment (Alesina and Perotti 1993). The theory holds true even when developed countries are included in the analysis. Income inequality creates a social distrust and drives up transaction costs and public expenditures on security related consumption not directly related to economic growth (Mo 2000). Model 3 includes median household income and the percent of the population below the federal poverty level as proxies for income distribution. This is due to the importance of income distribution in public allocation decisions, state expenditure decisions, and economic productivity.

Confirming prior research on income inequality effects on GDP, Model 3 shows median household income has a positive, statistically significant effect on per capita GDP. In addition, the percent of the population earning less than the federal poverty level has a negative, statistically significant impact on state per capita GDP. The findings indicate for every dollar increase in median household income, per capita GDP grows by \$0.16, a significant GDP growth in absolute terms. The percent of the population living below the federal poverty level has an even larger effect size, decreasing per capita GDP by $\$ 156$ for every 1 percent increase. Such findings confirm previous research that income distribution bear important implications for state GDP growth. In particular, income inequality, as represented by growth in the proportion of a state's population living on income below the federal poverty level, substantially decreases state economic output. Such findings support the theoretical importance of a healthy, robust, and growing middle class for economic growth (Easterly 2001). As median household income is a common indicator of the status and health of the middle class, growth in median household income could be expected to reflect growth in the economic strength and purchasing power of the middle class.

The unemployment rate is included to control for initial economic status and trend of the states. Continuous high unemployment rates can stagnate or drive down both household incomes and population growth (Glaeser et al. 1995). Due to the importance of human capital and consumption for endogenous growth, population growth can be particularly influential in state GDP. High unemployment rates, particularly over a long period of time, can drive down wages, discouraging inflows of new human capital. Low-skilled labor is especially affected, due to the elasticity of the demand for labor. (Glaeser et al. 1995). Including the unemployment rate in the model controls for initial differences across state economies and allows the model to control for variance in economic output due to unemployment rates. As noted prior, using per capita expenditures and per capita GDP controls for variance relates to population growth.

The findings indicate a large, negative impact on GDP growth tied to unemployment rates. In other words, as unemployment rates increase, the economic output of states decreases. However, the nature and direction of this relationship varies widely across states, and cannot be determined from the model. Unemployment rates may have lagged effects not controlled for or detected by the model. Also, short-term unemployment and longterm unemployment may have different effects and effect sizes on GDP. More comprehensive data, allowing for controls on the nature and structure of the unemployment rate across states could provide more robust and reliable estimates.

The model also includes the gender composition and union membership proportion of the entire workforce. Prior 
research has established a continuing wage gap between men and women of equal education, experience, and position (Blau and Kahn 2004). Wages among women began converging in the 1980's partly due to wages in occupations dominated by men falling as deunionization in those industries drove wages down. However, in the 1990's, decelerating union participation rates among men and women reached parity, and the wage gap continued (Blau and Kahn 2004). The persisting genderbased pay gap and higher wages from collective bargaining protections imply these two variables affect median income and income distribution in an economy.

The gender composition of the workforce influenced GDP in expected ways. As the percentage of the workforce made up by males increased, per capita GDP increases substantially. Conversely, as the female percentage of the workforce increases, per capita GDP declines slightly. The estimates on the gender variables are not statistically significant, indicating a wide variance in their effects across states. The negative estimate on the female variable likely reflects the longstanding and well-established gender pay gap referenced above. In the aggregate, the lower wages for female workforce participants drives average income down and creates a drag on state economic output. The variance in the gender variables across states observed in the model may be due to variance in the size and prevalence of the gender wage gap across states.

Union participation rates have a negative, statistically insignificant effect on per capita GDP, contradicting the expected direction. As unions drive wages higher and decrease income inequality, the expected outcome would be a positive effect on per capita GDP. The estimates of the effects of union participation rates on per capita GDP are not statistically significant, indicating a wide variance in the economic effects of union participation across states. The outcome could capture a trending decline in union membership, structural shifts away from manufacturing jobs frequently occupied by union members, or migration from regions dominated by unions. As will be discussed later, the large, statistically significant impact the manufacturing industry has on per capita GDP lends support to the theory that a decline in manufacturing jobs may explain the observed negative estimate of union membership.

Prior research also indicates the importance of the quality of human capital for GDP growth and income distribution. Studies examining the effects of education levels and spending on economic growth in developing nations have found a statistically significant, positive effect across multiple contexts and controlling for a variety of differences (Rahman 2011). Of course, developing nations could benefit from outsized marginal returns to education that may not apply to the United States; however, the positive correlation between education and GDP growth is evident in advanced, wealthy nations as well. A study of advanced nations that make up the Organization for Economic Cooperation and Development (OECD) also found that educational outcomes have a statistically significant, positive impact on growth (Hanushek and Woessmann 2011). In addition to the evidence from international studies, an analysis of statelevel data in the United State from 18402000, found that the average return in earnings per year of schooling for workers ranged from 11 percent to 15 percent, indicating a strong relationship between education and income in the United States (Turner et al. 2006). Another study of education spending in the United States found a significant positive correlation between communities with high average teacher salaries and GDP, and a significant negative correlation between communities with high drop-out rates and GDP, indicating the importance of quality education in economic growth (Faruq and Taylor 2011). The breadth and depth of these findings indicates that education levels of 
the workforce can have a significant influence on state GDP and income levels regardless of initial poverty or wealth. Consequently, Model 3 includes the percent of the population that graduated from high school and the percent of the population with a bachelor's degree to control for variance in education levels across states.

Surprisingly, the findings from the model go against the findings of previous research. Both education variables have a substantial, negative correlation with per capita GDP. In fact, the percent of the population with a high school diploma have a statistically significant negative correlation with per capita GDP. However, as the fluctuation in the estimates of these variables in Models 4 and 5 indicates, these variables are highly sensitive to model specification changes. The sensitivity and unanticipated outcome could be due to multicollinearity between the two variables, incomplete education data as discussed above, and other unobserved biases in the estimates.

Finally, Model 3 analyzes the differentiated effects of state economic activities and industrial structures. In order to analyze economic structural effects, the model contains variables capturing the proportion of a state's total economic output from the state's agricultural industry, manufacturing industry, and finance, insurance, and real-estate industries. As Model 3 indicates, the manufacturing industry provides, by far, the largest increase in per capita GDP growth. As the proportion of total state economic output from manufacturing increases by 1 percent, per capita GDP increases by nearly $\$ 400$. Of the three industrial variables, manufacturing has the largest effect size estimate on per capita GDP and is the only estimate to be statistically significant, indicating very little variance across states in the high, positive impact manufacturing has on state economic output. As Model 4 and Model 5 indicate, the GDP returns from manufacturing are not sensitive to specification, and do not lose their explan- atory power as other variables are added.

The large per capita GDP growth correlated with growth in manufacturing could be due to the large union presenceand correspondingly higher wages-in the manufacturing sector. The long-term trend away from manufacturing in the United States could explain the negative estimate in union membership and positive estimate from manufacturing. As manufacturing has declined in the United States, it may be at suboptimal levels, and consequently carries large marginal returns to increasing the presence of manufacturing in state economies. Similarly, the negative coefficient on union participation may be capturing a correlation between the decline of union-dominated, high-wage manufacturing jobs as manufacturing activities have declined and the resulting decrease in state GDP.

As Model 3 indicates, even controlling for the economic structure and workforce characteristics across states, state government expenditures yield a very high return in per capita GDP growth per dollar spent. The slight decline in the estimate for per capita expenditures indicates the estimated effect-size of state government spending is not sensitive to model specification. The strength of such findings indicates state governments and government expenditures will have an important role to play in sparking GDP growth needed to reduce unemployment rates and reverse the current recession. As growth in the manufacturing sector is also correlated with very high GDP growth relative to other industries, the model provides some insight into the potentially significant gains should states pursue policies and expenditures aimed at encouraging growth in manufacturing.

\section{Model 4: State Revenue Characteristics}

In Model 4, tax-related variables are added to explore the relationship between taxes and per capita GDP. Taxation theoretically influences consumption de- 
cisions and reduces consumption of taxed goods; therefore, what economic activities are taxed and at what level carries an implied influence on GDP. For instance, a study of an imposed tax on plastic bags in Ireland revealed that even a small tax created a very large reduction in plastic bag consumption and exerted great influence on consumer decisions (Convery et al. 2007). Research has also found differentiated impacts on GDP associated with corporate income, personal income, and production and import taxation. The research concluded that corporate income taxes should be increased and personal income taxes reduced when economic growth is needed. The inverse should be implemented in times of economic stability (Karagianni et al. 2012). Based on potential variation in GDP outcomes associated with variance in taxation decisions across states, Model 4 includes variables to control for variance in taxation approaches. The tax-related variables added are total tax revenues, and the proportion of total tax revenues from corporate income, personal income, property, and sales taxes as a proxy for tax levels. As mentioned earlier in the article, future studies would benefit from using tax rates, rather than revenue levels, to examine the true effects of taxation on GDP.

The results of the analysis examining taxation effects on GDP appear mixed. While previous research indicated that personal income taxes had negative effects on GDP and corporate and production taxes had little or no effect on GDP, Model 4 finds a positive correlation between both personal and corporate income tax revenues and GDP (Karagianni et al. 2012). However, the results find a higher GDP among states with a larger share of their revenue stream coming from corporate income taxes than from personal income taxes. Additionally, larger proportions of revenues from sales and property taxes have large, negative effects on per capita GDP across states. As sales and property taxes function as a tax on consumption, rather than production, the findings seem to confirm a drag on GDP associated with reducing consumer purchasing power. Similar to previous research, the differentiated effects from taxation seem to indicate tax policy should be shifted towards corporate income taxation in times of economic recession, reducing consumption disincentives created by personal income and consumption taxation. Not surprisingly, higher overall tax revenues correlate with positive, statistically significant per capita GDP growth. As state government expenditures generate positive GDP growth, states with greater revenue streams support a broader range of state activities and will likely see higher levels of economic output. Again, as before, after controlling for state taxation revenues to proxy for tax burdens, the Model still finds state government expenditures to have a positive, statistically significant, and substantial return in per capita GDP growth. Future studies would benefit from analyzing GDP effects from tax rates on various goods to examine more specific policy implications for taxation.

\section{Model 5: Political Characteristics of State Government}

In Model 5, indicator variables for Democratic control of the state Senate, House of Representatives, and governorship are included. As previously mentioned, only lag variables for one and two years are included to reflect the time policy changes take to fully impact an economy. While including lag variables along a longer timeframe would be ideal, the data available for this analysis do not permit lag variables longer than two years. Prior research has shown, however, that many spending initiatives, particularly government spending initiatives aimed specifically at improving economic output, show effects in the base year and a few years after adoption (Freedman et al. 2009). While this timeframe may be different for state government initiatives, the smaller scale of the economy and government activity may actually shrink the timeframe 
necessary to detect economic effects from some policy changes at the state level. Controlling for political party in power, the impact estimate for per capita spending actually increases slightly (from $\$ 1.89$ to $\$ 1.91$ ) and remains significant at all levels. The small size of the change, despite the change in specification, indicates the strength of the relationship between per capita state expenditures and per capita GDP. The political party in power provides little insight into the effects of party control on per capita GDP. The majority of the estimates indicate a negative impact on per capita GDP when the Democratic Party is in power; however, none of these findings are significantly different from zero at any level. The large standard errors for the coefficients indicate a wide variance around the results of party control. The variance is likely caused by instances of split governance creating constraints on enacting policies preferred by the party and intraparty differences in philosophic and policy approaches.

The estimates and significance of all of the political variables vary widely and are highly sensitive to the inclusion and exclusion of other political variables used in previous models (such as current party in power). The f-test confirms the unreliability of the political estimates, showing that the explanatory power of the political variables on per capita GDP is not statistically different from zero as a group. Such results indicate that political party control contributes little to models of state economies and carries no explanatory power for economic outcomes. State government policy, as indicated by state expenditures, provides far more insights into explaining economic outcomes. Consequently, identifying the policies most reflective of the economic and ideological differences between the parties and examining the outcomes in the states (or even communities) in which such policies were actually enacted would be a more effective way to study the relationship between politics and economic outcomes. Unfortunately, such data were not available for this study; thus, per capita state spending is used to proxy for such differences, and the findings, while accurate and significant, are not conclusive. Future studies with more comprehensive data would be useful.

\section{Conclusions}

As noted in the introduction, the recession in 2008 and high levels of longterm unemployment has made the role of government in economic affairs a topic of public debate. Using an endogenous growth model to estimate the differentiated effects of key economic inputs on state economies, the study isolated the effects of state government spending on GDP and found significant, positive marginal GDP returns per public expenditure. After modeling state economies, lag variables indicating the party in power were included and found no significant effect on GDP. The findings indicate that political party in control carries less explanatory power in economic outcomes than state government expenditures. The wide variance associated with GDP outcomes from party control reflects a wide variance in the policies implemented across state governments, even when controlled by the same party. As described in the introduction, the politicization of government spending drives nearly bipartisan adoption of cuts to public expenditures, with disagreements occurring only about the size and composition of the reductions. The examples provided by Governors Cuomo (D-NY) and Scott (R-FL) in the introduction indicate the policy impact of the politicization of government expenditure. Further, the Congressional Budget Office found for fiscal year 2010, 40 states cut education spending, and 31 governors proposed additional cuts to education in fiscal year 2011 (CBO 2010). Given the findings of the economic model developed in this paper regarding the GDP multiplier effects associated with public expenditures, the consequences of continued public spending reduction amidst a weak economy 
can slow economic recovery dramatically. Politicizing broadly defined government expenditures has driven a disconnection between the policy needs indicated by current economic circumstances, the models of state economies developed here, and the policies pursued by both parties.

Although by no means definitive or final, the models in this analysis provide preliminary indication that the state policies implemented by state governments provide a better explanation for economic outcomes than political party control. Such findings carry two implications. First, further research should be conducted to confirm the findings here using more complete data over a longer timeframe. In addition, future research should use the models introduced in this paper to explore the marginal returns in per capita GDP associated with various specific state activities. Analyzing the marginal returns in per capita GDP across types of government expenditure could provide a beginning point of comparison for policymakers when pursuing economic growth. Such an approach could help policymakers more accurately understand the economic trade-offs involved in spending decisions.

Second, the continued politicization of public expenditure (in general terms) on economic grounds should be revisited. Debates concerning appropriate state activities constitute a healthy political process, however, as this paper has demonstrated, casting all government spending as fundamentally damaging to economic growth misrepresents the fundamental effects on the economy. As the congressional showdown concerning federal spending levels described in the introduction highlights, politicizing government spending can have devastating consequences. As the findings indicate, policy dictates economic growth far more effectively than political control. The public debate should shift away from exclusively concentrating on reductions to public expenditure and towards debate surrounding more specific, targeted policy changes.

\section{References}

Alesina, Alberto, and Roberto Perotti. 1993. "Income Distribution, Political Instability, and Investment." NBER Working Paper Series: 1-33.

Barro, Robert J. 1977. "Unanticipated Money Growth and Unemployment in the United States." The American Economic Review: 101-115.

--—. 1988. "GOVERNMENT SPENDING IN A SIMPLE MODEL OF ENDOGENOUS GROWTH”. Cambridge: National Bureau of Economic Research.

---. 1991. "Economic Growth in a Cross Section of Countries." The Quarterly Journal of Economics: 407-443.

Blau, Francine D, and Lawrence M Kahn. 2004. "THE US GENDER PAY GAP IN THE 1990s: SLOWING CONVERGENCE”. Cambridge, MA: National Bureau of Economic Research:

Bureau of Labor Statistics. 2011. "The Employment Situation” December 2011. Washington DC: United States Bureau of Labor Statistics.

Burtless, Gary. 2010. "Is More Fiscal Stimulus Needed?” Council on Foreign Relations. http://www.cfr.org/economics/more-fiscal-stimulus-needed/ p22635.

Calmes, Jackie, and Carl Hulse. 2011. "Debt Ceiling Talks Collapse as Boehner Walks Out.” New York Times: http://www.nytimes.com/2011/o7/23/us/ politics $/ 23$ fiscal.html?pagewanted=all.

CBO (Congressional Budget Office) 2009a. The Budget and Economic Outlook.: Fiscal 
Years 2009 to 2019. Washington DC: United States Congressional Budget Of fice.

- - . 2009b. Estimated Impact of the American Recovery and Reinvestment Act on Employment and Economic Output as of September 2009.

Washington, DC:Congressional Budget Office.

- - . 2010. Fiscal Stress Faced by Local Governments. Washington, DC:

Congressional Budget Office, 2010.

- - . 2011a. Estimated Impact of the American Recovery and Reinvestment Act on Employment and Economic Output from July 2011 Through September 2011. Washington, DC: Congressional Budget Office.

- - . 2011b. Congressional Budget Office Impact Estimate of the Budget Control Act of 2011. Washington, DC: Congressional Budget Office.

Convery, Frank, Simon McDonnell, and Susana Ferreira. 2007. "The most popular tax in Europe? Lessons from the Irish plastic bags levy." Environmental Resource Economics.: 1-11.

Easterly, William. 2001. "The Middle Class Consensus and Economic Development.” Journal of Economic Growth.: 317-335.

Faruq, Hasan A, and Ashley C Taylor. 2011. "Quality of Education, Economic Performance and Institutional Environment”. New York, NY.: Springer..

Freedman, Charles, Michael Kumhof, Douglas Laxton, and Jaewoo Lee. 2009. IMF Staff Position Note.: The Case for Global Fiscal Stimulus. Washington, DC: International Monetary Fund.

Glaeser, Edward L, Jose A Sheinkman, and Andrei Shleifer. 1995. "Economic Growth in a Cross-section of Cities." Journal of Monetary Economics.: 117-143.

Govindaraju, V.G.R. Chandran, Ramesh Rao, and Sajid Anwar. 2010. "Economic growth and government spending in Malaysia.: a re-examination of Wagner and Keynesian views." Econ Change Restruct.: 203-219.

Grier, Kevin B, and Gordon Tullock. 1989. "An empirical analysis of cross national economic growth, 1950-1980.” Journal of Monetary Economics.: 259-276.

Hanushek, Eric A, and Ludger Woessmann. 2011. "How much do educational outcomes matter in OECD countries?” Economic Policy.: 427-491.

House Committee on the Budget. 2012. The Path to Prosperity: Restoring America's Promise. Legislative Proposal, Washington, DC: House Committee on the Budget.

Johnson, Simon, and James Kwak. 2010. 13 Bankers: The Wall Street Takeover and the Next Financial Meltdown. New York.: Pantheon Books.

Karagianni, Stella, Maria Pempetzoglou, and Anastasios Saraidaris. 2012. "Tax burden distribution and GDP growth: Non-linear causality considerations in the USA.” International Review of Economics and Finance.: 186-194.

Landefield, J. Steven, Eugene P Seskin, and Barbara M Fraumeni. 2008. "Taking the Pulse of the Economy: Measuring GDP.” Journal of Economic Perspectives.: 193-216.

Lizza, Ryan. 2009. "Inside the Crisis: Larry Summers and the White House economic team.” The New Yorker. http://www.newyorker.com/ reporting/2009/10/12/091012fa_fact_lizza (accessed January 1, 2012).

Lynch, David J. 2010. “Economists agree: Stimulus created nearly 3 million jobs.” USA Today.: http://www.usatoday.com/money/economy/2010-08-30-stimu lus30_CV_N.htm.

Media Matters. 2010. "Sunday show economic experts agree: more stimulus needed.” Media Matters.: http//mediamatters.org/research/201009050007. 
Mo, Pak Hung. 2000. "Income Inequality and Economic Growth."

KYKLOS.: 293-316.

New York State Government. 2012. New York State: ENACTED BUDGET FINANCIAL PLAN FOR FISCAL YEAR 2012. Albany, NY.: New York State Government.

Newport, Frank. 2011. "Republicans Remain Focused on Government Power, Spending.” Gallup.com. http://www.gallup.com/poll/146831/republicansremain-focused-government-power-spending.aspx (accessed January 1, 2012).

Office of Governor Rick Scott. 2012. "Fiscal Year 2012-2013: Policy and Budget Recommendations.” letsgettowork.state.fl.us. http://letsgettowork.state.fl.us/ reports/2012-Budget-Presentation-FY-2012-13.pdf (accessed January 20, 2012).

Palmer, Doug. 2011. "CBO raises TARP cost estimate to $\$ 34$ billion." reuters. com. http://www.reuters.com/article/2011/12/16/us-usa-tarp-costidUSTRE7BF1W920111216 (accessed January 16, 2012).

Rahman, Mostafizur. 2011. "Causal Relationship among Education Expenditure, Health Expenditure and GDP: A Case Study for Bangladesh.” International Journal of Economics and Finance.: 149-159.

Studenmund, A.H. 2005. Using Econometrics: A Practical Guide. New York City.: Pearson.

Taban, Sami. 2010. "An Examination of the Government Spending and Economic Growth Nexus for Turkey Using the Bound Test Approach.” International Research Journal of Finance and Economics.: 187-196.

Turner, Chad, Robert Tamura, Sean E Mulholland, and Scott Baier. 2006. "Education and income of the states of the United States: 1840-2000." Journal of Economic Growth.: 101-158.

United States Bureau of Economic Analysis. 2012. Gross Domestic Product: Fourth Quarter and Annual 2011. Washington, DC: United States Bureau of Economic Analysis.

United States Census Bureau. 2011. "Statistical Abstracts.” Census Bureau Web site. 2011. http://www.census.gov/prod/www/abs/statab.html (accessed April 5, 2011).

Weisbrot, Mark. 2010. "More Stimulus Needed to Reduce Unemployment.” Center for Economic and Policy Research. http://www.cepr.net/index.php/Op-Eds-Col umns/Op-Eds-Columns/more-stimulus-needed-to-reduce-unemployment (accessed January 3, 2012).

Yourish, Karen, and Laura Stanton. 2009. "Taking Apart the $\$ 819$ billion Stimulus Package." The Washington Post. http://www.washingtonpost.com/wp-dyn/ content/graphic/2009/02/01/GR2009020100154.html (accessed January 1, 2012).

Stephen Holt is graduating with his Master of Public Policy from The George Washington University. His concentration is program evaluation and management. He earned a Bachelor of Arts degree at the University of Florida with a double major in Political Science and English. He currently serves as a Research Assistant at Westat in the Education Studies Group.

Matthew M. McCreary is a Major in the US Army. He is in his final year of the Master of Public Policy program at The George Washington University where he is concentrating in 
national security policy. Matthew earned a Bachelor of Arts degree at The Ohio State University with a double major in Economics and Political Science. His next assignment will be as an interagency fellow at the Department of State. He is married to the former Gretchen Green from Marion, $\mathrm{OH}$, and they have two children, Harper Lee and Greyson Michael.

Lindsay Haslebacher is in her final year of the Master of Public Policy program at The George Washington University where she is concentrating in urban policy. Lindsay earned a Bachelor of Arts degree at The University of North Carolina at Chapel Hill with a double major in Public Policy and Political Science, with an interdisciplinary minor in "Philosophy, Politics, and Economics." She is currently a graduate fellow for Research and Assessment within The George Washington University's Student and Academic Support Services division.

Stephen thanks his co-authors for their continued support and assistance. Stephen would also like to thank Sarah Reinecke for allowing him to disappear into his computer into all hours of the night. Matthew thanks his co-authors for their hard work and efforts to see the project through to completion, and his family for their unconditional support.

Lindsay thanks her co-authors for their dedication and diligence.

The authors thank editors Rebecca Dilday, Anne Berry, Rachel Brody, and Josh Nadas for their comments, suggestions, and insights, without which the paper would surely have suffered. The authors would also like to thank Dr. Joseph Cordes for recommending submission of the paper and Dr. Nancy Potok for her valuable reviews and suggestions. 